\title{
Isolation of pathogenic microorganisms and determination of their antibiotic resistance patterns collected from different bakery products of Dhaka city
}

\author{
*Das, K.K., Sarkar, A. and Hossain, A. \\ Department of Microbiology, Stamford University Bangladesh, 51 Siddeswari Road, Dhaka 1217, \\ Bangladesh
}

\author{
Article history: \\ Received: 28 November 2019 \\ Received in revised form: 14 \\ January 2020 \\ Accepted: 23 January 2020 \\ Available Online: 22 \\ February 2020
}

Keywords:

Bakery products,

Microbiological analyses,

Antibiotic resistance,

Food quality

DOI:

https://doi.org/10.26656/fr.2017.4(4).400

\begin{abstract}
Bakery products play an important part in the diet of daily life and provide vital nutrients to human. But pathogenic microorganisms may get entry to bakery items through improper handling and storage which may lead some disease to consumers. For this reason, the objective of this study was to detect pathogenic bacteria in different bakery products collected from different places of Dhaka city. In this study, commonly consumed bakery items such as sweets, biscuit, cake and bread samples were collected from different locations for the detection of pathogenic microorganism. Here, all the samples were found to be contaminated huge microbial count up to $10^{6} \mathrm{CFU} / \mathrm{g}$. Klebsiella spp. and Pseudomonas spp. were most predominate among all. On the other hand, Escherichia coli was totally absent in all the samples. This result indicated that bakery products prepared under unhygienic environments and which may serve as a reservoir of various pathogenic bacteria and most of them were showed resistance against common antibiotics. To ensure the health safety of consumer's government should take necessary actions to educated food handlers.
\end{abstract}

\section{Introduction}

Bakery products are most consumed food worldwide and a good source of different essential nutrients such as carbohydrates, proteins, lipids, vitamins and minerals (Potter and Hotchkiss 2006; Saranraj and Geetha, 2012). As they contain low water activity and cooked under high temperature freshly baked products are free from microbes and do not contain pathogenic microorganisms therefore from the microbiological point of view bakery products are generally considered as safe food (ICMSF 2002; Saddozai and Khalil, 2009; Saranraj and Geetha 2012; Khanom et al., 2016). Cooking method, lower $\mathrm{pH}$, the addition of preservative and low moisture in bakery items can prevent products from bacterial spoilage and also extended their self-life (Berghofer et al., 2003).

But improper storage conditions, unhygienic handling may support the proliferation of various microorganisms in cereal grains and bakery products (Deibel and Swanson, 2001). Some common bacteria like Bacillus sp. and mold include Rhizopus sp., Mucor sp., Penicillium sp., Eurotium sp., Aspergillus sp. and Monilia sp. are responsible for spoilage which depends on seasons, type of products and methods of processing (Seiler, 2000; Saranraj and Geetha 2012). Several studies conducted in various countries have reported that food poisoning resulting from contaminated flour (Saddozai and Khalil, 2009; Saranraj and Geetha 2012; Khanom et al., 2016). Butothers research on wheat and flour were reported that they contain pathogenic microorganisms like Salmonella spp., Escherichia coli, Bacillus cereus and other spoilage micro-organisms in low levels (Richter et al., 1993; Victor et al., 2013). So, it would be different physical, chemical and microbial factor-like slicing equipment, post-baking contamination from the handler, bread coolers, conveyor belts, racks and high moisture can also influence the spoilage of bakery products (Saddozai and Khalil, 2009; Saranraj and Geetha 2012). Bakery products come in contact with moulds, yeasts and bacteria such as the rope-causing heat - resistant endospore-forming Bacillus subtilis during production and inappropriate storage (Earle and Putt, 1984). Mold spores are killed in the baking process (Knight and Menlove, 1961), leaving often contamination to be the source of spoilage problems. Penicillium is the most common fungal contaminants which also necessary for sourdough bread (Legan and Voysey, 1991). Some bacterial spore-like Bacillus spores are very dangerous because of its ability to survive in high temperature also in the baking period which may be germinated after baking or during storage (Legan, 1993). Several studies on food reported that contaminated and 
unhygienic products have been associated with foodborne illness, for this reason, analyses of bakery products are essential as these may affect the overall health of the persons and consumers (Saranraj and Geetha, 2012).

The objective of this study was to investigate the microbiological quality of the bakery samples collected from the market of Dhaka city and determination of antibiotic resistance patterns of isolated pathogens.

\section{Materials and methods}

\subsection{Study area, sampling and sample processing}

Different bakery products were collected from markets early in the morning after production. All samples were instantly transported to the Microbiological Laboratory at Stamford University Bangladesh, Dhaka. Each sample $(10.0$ g) was homogenized with $90.0 \mathrm{~mL}$ of sterile normal saline to prepare a stock solution. Stocks were serially diluted up to $10^{-5}$ by adding $1 \mathrm{~mL}$ of samples on a series of $9 \mathrm{~mL}$ of normal saline.

\subsection{Microbiological analysis of each sample}

A volume of $0.1 \mathrm{~mL}$ from each sample suspension was spread onto nutrient agar (NA) and incubated at $37^{\circ}$ $\mathrm{C}$ for $24 \mathrm{hrs}$ for enumerating total viable bacteria (TVB). Sabouraud dextrose agar (SDA) (Oxoid Ltd., Basingstoke, Hampshire, England) was inoculated followed by incubation at $25^{\circ} \mathrm{C}$ for $48 \mathrm{hrs}$ for the isolation of fungi (Noor et al. 2013; Rahman et al., 2016)

\subsection{Isolation pathogenic microorganisms}

For the isolation of coliform bacteria (Escherichia coli, Klebsiella spp.), $0.1 \mathrm{~mL}$ of each sample suspension was spread over MacConkey (Oxoid Ltd., Basingstoke, Hampshire, England) agar and incubated at $37^{\circ} \mathrm{C}$ for 24 hours.

$0.1 \mathrm{~mL}$ of each sample suspension was spread on mannitol salt agar (MSA) (Oxoid Ltd., Basingstoke, Hampshire, England) for the estimation of Staphylococcus aureus and the plates were incubated at $37^{\circ} \mathrm{C}$ for $24 \mathrm{hrs}$. For the estimation of starch hydrolyzing bacteria (Bacillus spp.), $0.1 \mathrm{~mL}$ of each sample suspension was spread onto starch agar (SA) (Oxoid Ltd., Basingstoke, Hampshire, England) and incubation at $37^{\circ} \mathrm{C}$ for $24 \mathrm{hrs}$.

For the enumeration of Pseudomonas spp., $0.1 \mathrm{~mL}$ of each sample suspension was spread onto Pseudomonas agar (Oxoid Ltd., Basingstoke, Hampshire, England) and plates were incubated at $37^{\circ} \mathrm{C}$ for $24 \mathrm{hrs}$. All the microorganisms were further confirmed by biochemical methods (Cappuccino and Sherman, 1996; Rahman et al., 2016; Noor et al., 2013; Marjan et al., 2014; Rahman et al., 2016; Rahman et al., 2016).

\subsection{Enrichment of Salmonella spp., Shigella spp. and Vibrio spp.}

The in vitro cultivation of the species of Salmonella, Shigella and Vibrio often appears difficult or with faulty results (false-negative) due to their viable but nonculturable (VBNC) attributes (Colwell, 2000; Oliver, 2005; Das et al., 2013). Consequently, enrichment was used prior to isolating these bacteria (Rahman and Noor, 2012; Ahmed et al., 2014). For the isolation of Salmonella spp. and Shigella spp., $1 \mathrm{~mL}$ of homogenized sample suspension was transferred to selenite cystine broth (SCB) and for Vibrio spp.1 $\mathrm{mL}$ of sample was transferred to alkaline peptone water (APW) then incubated at $37^{\circ} \mathrm{C}$ for $4-6 \mathrm{hrs}$. After incubation samples were serial diluted up to $10^{-4}$ and from $10^{-4}$ dilution 0.1 $\mathrm{mL}$ was spread onto Salmonella Shigella (SS) agar (Hi media, India) and TCBS (Hi media, India) respectively for Salmonella spp., Shigella spp. and Vibrio spp. (Noor et al., 2013; Rahman et al., 2016).

\subsection{Antibiotic susceptibility test}

Antibiotic susceptibility traits of the pathogenic isolates were examined by disc diffusion method where bacterial suspension $\left(10^{5}\right.$ cells or $\left.0.5 \mathrm{OD}\right)$ were prepared from isolated pathogens. Then bacterial lawn was done on Mueller-Hinton agar (Oxoid Ltd., Basingstoke, Hampshire, England) plates and commercially available laboratory-grade antibiotic discs (Ampicillin $(10 \mu \mathrm{g})$, Ciprofloxacin $(5 \mu \mathrm{g})$, Streptomycin $(10 \mu \mathrm{g})$, Ceftriaxone (30 $\mu \mathrm{g})$, Imipenem $(30 \mu \mathrm{g})$, Penicillin $(10 \mu \mathrm{g})$, Gentamycin $(10 \mu \mathrm{g})$, Azithromycin $(15 \mu \mathrm{g})$, Tetracycline (30 $\mu \mathrm{g})$, Cefixime $(5 \mu \mathrm{g})$, Erythromycin $(15 \mu \mathrm{g})$ and Trimethoprim-Sulfamethoxazole $(25 \mu \mathrm{g})$ were aseptically placed on the surface of agar plates at spatial distance of $5 \mathrm{~mm}$ (Marjan et al., 2014).

\section{Results and discussion}

Different studies have observed that bakery products are an important portion of energy intake (Agte et al., 2002; Bartrina et al., 2004; Vanelli et al., 2005). But post preparation contamination is a serious problem for public health. Food safety authority's make some food standard the maximum permissible limits in baked products (cake, bread and biscuits) for total plate count (TPC) is $<10^{5}$ $\mathrm{CFU} / \mathrm{g}$, yeast and mold is $<10^{4} \mathrm{CFU} / \mathrm{g}$, coliform bacteria $<200 \mathrm{CFU} / \mathrm{g}$, E. coli absent (Gilbert et al., 2000; Hocking, 2003; NSW Food Authority, 2009).

The present study revealed that all the samples were 
found to be contaminated with heterotrophic bacteria within the range of $10^{4}$ to $10^{7} \mathrm{CFU} / \mathrm{g}$ (Table 1). Six out of twenty samples exceeded the microbial limit. The proliferation of bacteria may lead to disease if bakery items consumed by immune-compromised patient or children which is a serious problem for the buyer. In the case of total fungi, all the bakery items were found to harbor microorganisms within the range of $10^{2}$ to $10^{3} \mathrm{CFU} / \mathrm{g}$ which is under the microbial limit.

In the case of specific microflora the growth of Klebsiella spp., Pseudomonas spp. are most predominate those are confirmed by biochemical identification (table 2). Klebsiella spp. are found on all the samples within a range of $10^{2}-10^{5} \mathrm{CFU} / \mathrm{g}$ which is very alarming which also sheds light on the unhygienic processing conditioning. Pseudomonas spp. is ubiquitous organisms which can be found everywhere, but the presence in food was not acceptable. Here, out of ten samples, only six contain Pseudomonas spp. E. coli was totally absent in all the samples. Among the four samples, most of the bread and cake were contaminated with Staphylococcus spp. Therefore, it can be inferred that these baked products were not handled in an appropriate manner by the workers. Consuming Staphylococcus spp. also can cause diseases such as nausea and vomiting, they should use gloves and do not use outside clothing in possessing areas. Surprisingly, Salmonella spp. also found to be harboring in two samples, which may come from poultry products like eggs or milk (Table 1). In the bakery, they use egg in cake, bread and biscuits which major source of Salmonella spp. so egg should wash before formulation. Vibrio spp. was also present in three bakery items and water used in bakery may the possible source of these types of result.

Unacceptable levels of bacteria might result from this study may be due to poor hygienic practices, from dirty equipment and polluted environments of processing and storage area. Compare to other sweets items harbor less microbial count may be due to its high sugar content. Prevalence of drug-resistance gene is growing day by day within the human body through the ingestion of drug-resistant bacteria by water, food and pharmaceuticals (Ahmed et al., 2013; Hassan et al., 2013). A different study on food water and pharmaceuticals products revealed that they contain drug -resistant bacteria (Noor et al., 2013; Ahmed et al., 2013; Marjan et al., 2014). In this study similarly, all pathogenic isolates were resistant against multiple antibiotics tested (Table 3). Among the five pathogens Staphylococcus spp. and Pseudomonas spp. exhibited more resistance against tested antibiotics which indicates them as the MDR strain. However, other pathogenic strain also contains resistant genes (Table 3). Abuse use of antibiotics may be a possible reason behind the development of drug-resistant strain which may generate serious health threat for consumers (Marjan et al., 2014).

Table 1. Microbiological analysis of some bakery items

\begin{tabular}{|c|c|c|c|c|c|c|c|c|c|}
\hline \multicolumn{2}{|c|}{ Sample } & TVB & $\begin{array}{l}\text { Total } \\
\text { fungus }\end{array}$ & E. coli & $\begin{array}{l}\text { Klebsiella } \\
\text { spp. }\end{array}$ & $\begin{array}{c}\text { Staphylococcus } \\
\text { spp. }\end{array}$ & Vibrio spp. & $\begin{array}{l}\text { Salmonella } \\
\text { spp. }\end{array}$ & $\begin{array}{l}\text { Pseudomonas } \\
\text { spp. }\end{array}$ \\
\hline \multirow{4}{*}{ Baily road } & Sweet & $9.2 \times 10^{4}$ & $2.4 \times 10^{2}$ & 0 & $1.0 \times 10^{2}$ & 0 & 0 & 0 & 0 \\
\hline & Biscuit & $6.5 \times 10^{4}$ & $2.6 \times 10^{2}$ & 0 & $5.0 \times 10^{2}$ & $1.7 \times 10^{2}$ & 0 & 0 & 0 \\
\hline & Cake & $5.6 \times 10^{5}$ & $2.2 \times 10^{2}$ & 0 & $1.3 \times 10^{1}$ & $1.2 \times 10^{2}$ & 0 & 0 & 0 \\
\hline & Bread & $2.1 \times 10^{6}$ & $2.6 \times 10^{3}$ & 0 & $1.2 \times 10^{1}$ & $1.5 \times 10^{2}$ & 0 & 0 & 0 \\
\hline \multirow{4}{*}{ Shantinagar } & Sweet & $3.4 \times 10^{4}$ & $4.6 \times 10^{2}$ & 0 & 0 & 0 & 0 & 0 & 0 \\
\hline & Biscuit & $2.4 \times 10^{5}$ & $5.4 \times 10^{3}$ & 0 & $1.2 \times 10^{2}$ & 0 & 0 & 0 & 0 \\
\hline & Cake & $7.5 \times 10^{5}$ & $1.5 \times 10^{2}$ & 0 & $1.1 \times 10^{2}$ & $1.7 \times 10^{2}$ & 0 & 0 & $8.8 \times 10^{2}$ \\
\hline & Bread & $6.5 \times 10^{6}$ & $2.8 \times 10^{3}$ & 0 & $1.3 \times 10^{2}$ & $2.1 \times 10^{2}$ & 0 & 0 & $3.0 \times 10^{2}$ \\
\hline \multirow{4}{*}{ Mouchak } & Sweet & $1.9 \times 10^{4}$ & $5.6 \times 10^{3}$ & 0 & 0 & 0 & 0 & $2.0 \times 10^{2}$ & 0 \\
\hline & Biscuit & $2.4 \times 10^{5}$ & $4.8 \times 10^{3}$ & 0 & 0 & 0 & $9.5 \times 10^{3}$ & $3.8 \times 10^{3}$ & 0 \\
\hline & Cake & $5.3 \times 10^{5}$ & $3.2 \times 10^{2}$ & 0 & $3.6 \times 10^{3}$ & $2.5 \times 10^{2}$ & 0 & 0 & 0 \\
\hline & Bread & $4.1 \times 10^{6}$ & $5.2 \times 10^{3}$ & 0 & $2.3 \times 10^{2}$ & $1.8 \times 10^{2}$ & 0 & 0 & 0 \\
\hline \multirow{4}{*}{ Khilgoan } & Sweet & $1.1 \times 10^{3}$ & $4.6 \times 10^{2}$ & 0 & 0 & 0 & 0 & 0 & 0 \\
\hline & Biscuit & $1.9 \times 10^{4}$ & $1.2 \times 10^{3}$ & 0 & 0 & 0 & 0 & 0 & 0 \\
\hline & Cake & $8.6 \times 10^{5}$ & $3.4 \times 10^{2}$ & 0 & $3.3 \times 10^{2}$ & $2.1 \times 10^{2}$ & 0 & 0 & $8.0 \times 10^{2}$ \\
\hline & Bread & $3.9 \times 10^{6}$ & $4.4 \times 10^{3}$ & 0 & $5.6 \times 10^{1}$ & $2.2 \times 10^{3}$ & 0 & 0 & $4.1 \times 10^{2}$ \\
\hline \multirow{4}{*}{ Siddeshwari } & Sweet & $2.9 \times 10^{4}$ & $1.2 \times 10^{2}$ & 0 & $2.0 \times 10^{1}$ & 0 & 0 & 0 & 0 \\
\hline & Biscuit & $2.8 \times 10^{5}$ & $1.7 \times 10^{2}$ & 0 & 0 & 0 & 0 & 0 & 0 \\
\hline & Cake & $1.9 \times 10^{7}$ & $2.4 \times 10^{3}$ & 0 & $2.0 \times 10^{2}$ & $3.3 \times 10^{2}$ & $2.2 \times 10^{3}$ & 0 & $5.2 \times 10^{3}$ \\
\hline & Bread & $1.8 \times 10^{7}$ & $2.1 \times 10^{3}$ & 0 & $1.3 \times 10^{2}$ & $4.0 \times 10^{2}$ & $7.5 \times 10^{2}$ & 0 & $3.1 \times 10^{3}$ \\
\hline
\end{tabular}


Table 2. Biochemical reaction chart of different isolates to identify different bacteria

\begin{tabular}{ccccccccccc}
\hline $\begin{array}{c}\text { Assumed } \\
\text { Organism }\end{array}$ & slant & butt & gas & creation & test & test & VP test & $\begin{array}{c}\text { Citrate } \\
\text { test }\end{array}$ & Motility & $\begin{array}{c}\text { Oxidase } \\
\text { test }\end{array}$ \\
\hline Klebsiella spp. & $\mathrm{Y}$ & $\mathrm{Y}$ & + & - & - & - & + & + & - \\
Vibrio spp. & $\mathrm{Y}$ & $\mathrm{Y}$ & - & - & + & + & - & + & + \\
Salmonella spp. & $\mathrm{R}$ & $\mathrm{Y}$ & - & + & - & + & - & - & + \\
Pseudomonas & $\mathrm{R}$ & $\mathrm{R}$ & - & - & - & - & - & + & + \\
\hline
\end{tabular}

Y: Yellow (Acid), R: Red (Alkaline), MR: Methyl red, VP: Voges-Proskauer

Table 3. Antibiogram of different isolates from bakery products.

\begin{tabular}{|c|c|c|c|c|c|c|c|c|c|c|}
\hline \multirow[t]{2}{*}{ Antibiotics } & \multicolumn{2}{|c|}{$\begin{array}{l}\text { Klebsiella spp. } \\
\quad \mathrm{n}=14\end{array}$} & \multicolumn{2}{|c|}{$\begin{array}{c}\text { Staphylococcus spp. } \\
n=11\end{array}$} & \multicolumn{2}{|c|}{$\begin{array}{c}\text { Vibrio spp. } \\
\mathrm{n}=3\end{array}$} & \multicolumn{2}{|c|}{$\begin{array}{l}\text { Salmonella spp. } \\
\quad n=2\end{array}$} & \multicolumn{2}{|c|}{$\begin{array}{l}\text { Pseudomonas spp. } \\
\mathrm{n}=6\end{array}$} \\
\hline & $\mathrm{R}$ & $\mathrm{S}$ & $\mathrm{R}$ & $S$ & $\mathrm{R}$ & $\mathrm{S}$ & $\mathrm{R}$ & $\mathrm{S}$ & $\mathrm{R}$ & $\mathrm{S}$ \\
\hline AMP $(10 \mu \mathrm{g})$ & $7.50 \%$ & $92.80 \%$ & $90.90 \%$ & $9.40 \%$ & $66.60 \%$ & $33.40 \%$ & $0 \%$ & $100 \%$ & $83.30 \%$ & $16.70 \%$ \\
\hline CIP $(5 \mu \mathrm{g})$ & $0 \%$ & $100 \%$ & $100 \%$ & $0 \%$ & $0 \%$ & $100 \%$ & $0 \%$ & $100 \%$ & $83.30 \%$ & $16.70 \%$ \\
\hline $\operatorname{STE}(10 \mu \mathrm{g})$ & $0 \%$ & $100 \%$ & $54.50 \%$ & $45.50 \%$ & $66.60 \%$ & $33.40 \%$ & $0 \%$ & $100 \%$ & $66.60 \%$ & $33.40 \%$ \\
\hline CEF $(30 \mu \mathrm{g})$ & $28.60 \%$ & $71.40 \%$ & $81.80 \%$ & $18.20 \%$ & $33.30 \%$ & $66.70 \%$ & $0 \%$ & $100 \%$ & $50 \%$ & $50 \%$ \\
\hline IPM $(30 \mu \mathrm{g})$ & $35.80 \%$ & $64.20 \%$ & $100 \%$ & $0 \%$ & $66.60 \%$ & $33.40 \%$ & $50 \%$ & $50 \%$ & $66.60 \%$ & $33.40 \%$ \\
\hline PEN $(10 \mu \mathrm{g})$ & $57.20 \%$ & $42.80 \%$ & $100 \%$ & $0 \%$ & $100 \%$ & $0 \%$ & $100 \%$ & $0 \%$ & $83.30 \%$ & $16.70 \%$ \\
\hline $\operatorname{GEN}(10 \mu \mathrm{g})$ & $0 \%$ & $100 \%$ & $0 \%$ & $100 \%$ & $0 \%$ & $100 \%$ & $0 \%$ & $100 \%$ & $16.70 \%$ & $83.30 \%$ \\
\hline 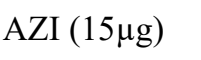 & $28.60 \%$ & $71.40 \%$ & $63.60 \%$ & $36.40 \%$ & $0 \%$ & $100 \%$ & $50 \%$ & $50 \%$ & $33.40 \%$ & $66.60 \%$ \\
\hline TER $(30 \mu \mathrm{g})$ & $0 \%$ & $100 \%$ & $36.40 \%$ & $63.60 \%$ & $33.40 \%$ & $66.60 \%$ & $50 \%$ & $50 \%$ & $50 \%$ & $50 \%$ \\
\hline CFX $(5 \mu \mathrm{g})$ & $57.20 \%$ & $42.80 \%$ & $72.70 \%$ & $27.30 \%$ & $33.40 \%$ & $66.60 \%$ & $100 \%$ & $0 \%$ & $50 \%$ & $50 \%$ \\
\hline ERY $(15 \mu \mathrm{g})$ & $57.20 \%$ & $42.80 \%$ & $90.90 \%$ & $9.40 \%$ & $33.40 \%$ & $66.60 \%$ & $50 \%$ & $50 \%$ & $66.60 \%$ & $33.40 \%$ \\
\hline SXT $(25 \mu \mathrm{g})$ & $0 \%$ & $100 \%$ & $9.40 \%$ & $90.90 \%$ & $33.40 \%$ & $66.60 \%$ & $50 \%$ & $50 \%$ & $16.70 \%$ & $83.30 \%$ \\
\hline
\end{tabular}

$\mathrm{AMP}=$ Ampicillin; CIP = Ciprofloxacin; STE = Streptomycin ; CEF = Ceftriaxone ; IPM = Imipenem ; PEN = Penicillin ; GEN $=$ Gentamycin $; \mathrm{AZI}=$ Azithromycin $; \mathrm{TER}=$ Tetracycline $; \mathrm{CFX}=$ Cefixime $; \mathrm{ERY}=$ Erythromycin $; \mathrm{SXT}=\mathrm{Trimethoprim}-$ Sulfamethoxazole.

\section{Conclusion}

The present study revealed the microbiological and hygienic status of filled bakery products. Overall, the microbiological status of filled bakery products was slightly good while other samples were found to be contaminated with different microbes including disease causing bacteria with higher counts than accepted limits. The presence of those microbes in bakery products indicated an alarming situation for the final consumer. So, maintenance of hygienic practice during preparation of bakery products and use of standard procedure to reduce the cross contamination from raw materials is also necessary to ensure public health safety. However, the food quality in Bangladesh needs to be monitored regularly by BSTI and by the Ministry of Health in Bangladesh.

\section{Conflict of Interest}

The authors declare no conflict of interest.

\section{Acknowledgments}

We thank Microbiology Laboratory, Stamford University Bangladesh for laboratory facilities, technical assistance and financial aid.

\section{References}

Agte, V., Tarwadi, K., Mengale, S., Hinge, A. and Chiplonkar, S. (2002). Vitamin profile of cooked foods: how healthy is the practice of ready-to-eat foods? International Journal of Food Sciences and Nutrition, 53(3), 197-208. https:// doi.org/10.1080/09637480220132814

Ahmed, T., Baidya, S., Sharma, B.C., Malek, M., Das, K.K., Acharjee, M., Munshi, S.K. and Noor, R. (2013). Identification of drug-resistant bacteria among export quality shrimp samples in Bangladesh. Asian Journal of Microbiology, Biotechnology and Environmental Sciences, 15(4), 31-36.

Bartrina, A.J., Rodrigo, P.C., Majem, S.L. and Rubio, D.A. (2004). Food habits of students using school dining rooms in Spain. "Tell Me How You Eat" Study. Atención Primaria, 33(3), 131-139. https:// doi.org/10.1016/S0212-6567(04)79373-7

Berghofer, L.K., Hocking, A.D., Miskelly, D. and Jansson, E. (2003). Microbiology of wheat and flour milling in Australia. International Journal of Food Microbiology, 85(1-2), 137-149. https:// 
doi.org/10.1016/S0168-1605(02)00507-X

Cappuccino, G. and Sherman. N. (2001). Microbiology laboratory manuals., $7^{\text {th }}$ ed. San Francisco: Pearson/ Benjamin Cummings.

Das, K.K., Fatema, K.K., Nur, I.T. and Noor, R. (2013). Prevalence of microorganisms in commonly used cosmetics samples in Dhaka Metropolis. Journal of Pharmaceutical Science and Innovation, 2(6), 7-9. https://doi.org/10.7897/2277-4572.02684

Deibel, K.E. and Swanson, K.M.J. (2001). Cereal and cereal products. In Downes, P.F. and Ito, K. (Eds). Microbiological examination of foods. Washington D.C.: American Public Health Association (APHA). https://doi.org/10.2105/9780875531755ch55

Earle, M.D. and Putt, G.J. (1984). Microbial spoilage and use of sorbates in bakery products. Food Technology in New Zealand, 11, 25-36.

Gilbert, R.J., de Louvois, J., Donovan, T., Little, C., Nye, K., Ribeiro, C.D., Richards, J., Roberts, D., Bolton, F.J. (2000). Guidelines for the microbiological quality of some ready-to-eat foods samples at the point of sale. Communicable Disease and Public Health, 3, 163-167.

Hassan, M.R., Acharjee, M., Das, E., Das, K.K., Ahmed, T., Akond, M.A., Fatema, K.K. and Noor, R. (2013). Microbiological study of sea fish samples collected from local markets in Dhaka city. International Food Research Journal, 20(3), 1491-1495.

Hocking, A.D. (ed.) (2003). Foodborne Microorganisms of Public Health Significance. $6^{\text {th }}$ ed. Waterloo: Australian Institute of Food Science and Technology.

International Commission on Microbiological Specification of Food (ICMSF). (2002). Microorganisms in Foods 7. Microbiological testing in food safety management. New York, USA: Kluwer Academic/Plenum Publishers.

Khanom, A., Shammi T. and Kabir, M.S. (2016). Determination of microbiological quality of packed and unpacked bread. Stamford Journal of Microbiology, 6(1), 24-29. https://doi.org/10.3329/ sjm.v6i1.33515

Knight, R.A. and Menlove, E.M. (1961). Effect of the bread-baking process on destruction of certain mould spores. Journal of the Science of Food and Agriculture, 12(10), 653- $656 . \quad \mathrm{https} / /$ doi.org/10.1002/jsfa.2740121001

Legan, J.D. and Voysey, P.A. (1991). Yeast spoilage of bakery products and ingredients. Journal of Applied Bacteriology, 70(5), 361-371. https:// doi.org/10.1111/j.1365-2672.1991.tb02950.x

Legan, J.D., (1993). Mould spoilage of bread: the problem and some solutions. International
Biodeterioration and Biodegradation, 32(1-3), 3353. https://doi.org/10.1016/0964-8305(93)90038-4

Marjan, S., Das, K.K., Munshi, S.K. and Noor, R. (2014). Drug-resistant bacterial pathogens in milk and some milk products. Nutrition and Food Science, 44(3), 241-248. https://doi.org/10.1108/NFS -05-2013-0061

Noor, R., Acharjee, M., Ahmed, T., Das, K.K., Paul, L., Munshi, S.K., Urmi, N.J., Rahman, F. and Alam, M.Z. (2013). Microbiological analysis of major sea fish collected from local markets in Dhaka city, Bangladesh. The Journal of Microbiology, Biotechnology and Food Sciences, 2(4), 2420-2430.

NSW Food Authority. (2009). Microbiological quality guide for ready-to-eat foods. A guide to interpreting microbiological results. Australia: NSW Food Authority.

Potter, H. and Hotchkiss, I. (2006). Food Science. $5^{\text {th }}$ ed. New Delhi, India: CBS Publishers and Distributors.

Rahman, H., Feroz, F., Alam, M.S., Das, K.K. and Noor, R. (2016). Demonstration of the source of microbial contamination of freshly cultivated cabbage, cauliflower, potato and squash collected from rural farms of Bangladesh. International Food Research Journal, 23(3), 1289-1295.

Richter, K.S., Dorneanu, E., Eskridge, K.M. and Rao, C.S. (1993). Microbiological quality of flours. Cereal Food World, 38, 367-369.

Saddozai, A.A. and Khalil. S. (2009). Microbiological status of bakery products available in Islamabad. Pakistan Journal of Agricultural Research, 22, 9396.

Saranraj, P. and Geetha, M. (2012). Microbial Spoilage of Bakery Products and Its Control by Preservatives. International Journal of Pharmaceuticaland Biological Archives, 3(1), 38-48.

Seiler, D.A.L. (2000). Modified atmosphere packaging of bakery products. In Brody, A.L. (Ed.) Controlled/ Modified Atmosphere/Vaccum Packaging of Foods., p. 119-133. USA: Taylor and Francis.

Vanelli, M., Lovane, B., Bernardini, A., Chiari,G., Errico, M.K.,Gelmetti, C.,Corchia, M., Ruggerini, A., Volta, E. and Rossetti, S. (2005). Breakfast habits of 1,202 northern Italian children admitted to a summer sport school. Breakfast skipping is associated with overweight and obesity. Acta Biomedica Atenei Parmensis, 76(2), 79-85.

Victor, N., Bekele, M.S., Ntseliseng, M., Makotoko, M., Peter, C. and Asita, A.O. (2013). Microbial and Physicochemical Characterization of Maize and Wheat Flour from a Milling Company, Lesotho. Internet Journal of Food Safety, 15, 11-19. 